\title{
Actividades Com os Pais no Computador (APC)
}

JoÃo C. M. PAIVA*

\begin{abstract}
$D$ escreve-se neste artigo uma proposta de um novo estilo de actividades educativas envolvendo os pais (ou outros familiares) dos alunos e os computadores. $O$ triângulo paisalunos-computador é complexo e não raras vezes tumultuoso, principalmente porque 0 computador (com as iniciativas de jogos e msn, em particular) é visto pelos pais como um 'inimigo do estudo'. Actividades com os Pais no Computador (APC) são iniciativas do professor que visam uma conciliação e potenciação pedagógica do computador, no contexto das relações familiares, com uma grande abertura ao mundo (pela janela da Internet). É uma sistematização de algumas práticas já experimentadas, onde se preconiza uma adaptação da escola às necessidades da sociedade de informação, que não sacrifica mas antes tonifica os afectos da "instituição família".
\end{abstract}

\section{INTRODUÇÃO}

Os pais "lutam" com os filhos por causa do computador. Talvez porque a maioria dos encarregados de educação, muitas vezes com razão, entendem que as actividades dos filhos no computador subtraem tempo e qualidade ao estudo. Por outro lado, é verdade que o computador é uma ferramenta chave da Sociedade de Informação em que vivemos e é parte integrante da actual "geração zap" [1].

A chave deste dilema está na conciliação entre os pais, o computador e os filhos. E quem pode incentivar e protagonizar, muito em particular, esta conciliação? A escola! Mais concretamente os professores, propondo actividades que tirem proveito da máquina e potenciem uma aprendizagem substancial, moderna e agradável, fomentando ao mesmo tempo que pais e filhos se liguem e tenham à volta destas actividades claros pretextos para se aproximarem, cognitiva e afectivamente.

O cerne deste artigo é a contextualização e proposta daquilo a que chamámos APC (Actividades com os Pais no Computador).

Este texto corresponde a um plano de intenções daquilo que julgamos

Departamento de Química e Bioquímica, Faculdade de Ciencias da Universidade do Porto E-mail: jcpaiva@netcabo.pt ser uma "boa ideia". Não é algo que nasça do nada, uma vez que experiências convergentes com o que se propõe têm vindo a ser feitas em vários grupos de investigação. Pretendemos sistematizar algumas ideias e dar passos para estimular e "instituir" estas actividades, no sentido de as tornar mais frequentes e regulares. Não seremos exaustivos nesta intervenção escrita, preferindo apontar as principais ideias, relegando para outro momento uma maior exaustão nas fundamentações, bem como o relato e avaliação pormenorizados de experiências em curso. Trata-se, neste momento, de identificar uma estratégia e lançar um desafio, a nós próprios e a toda a comunidade que se interessa pelas tecnologias e pela educação. Começamos por evidenciar as principais fontes de inspiração que nos motivaram (secção 2), caracterizando de seguida algumas linhas de força gerais das APC (secção 3). Na secção 4 lançamos propostas para um futuro próximo, incluindo algumas que estão já em desenvolvimento. Finalmente, na última secção apresentamos algumas conclusões. De notar que este número do Boletim da SPQ apresenta um exemplo concreto de uma APC, elaborado por Carla Morais, em estreita ligação com este artigo.

\section{FonTES DE INSPIRAÇÃO}

Referenciamos as ideias mais marcantes de algumas fontes de inspiração das APC. a) A complexidade da sociedade actual e as necessidades educativas e produtivas que a sustentam têm nas ideias de Peter Senge [2] um enquadramento feliz, na nossa perspectiva. Ao referir as suas cinco disciplinas, Senge chama a atenção que cada vez mais a sociedade, e o mundo empresarial, em particular, carecem de indivíduos com novas aptidões (transferíveis) e grande capacidade de adaptação ao paradigma da mudança, que caracteriza a Sociedade do Conhecimento. O seu "pensamento sistémico" introduz-nos na complexidade dos sistemas (as coisas estão mais ligadas do que parecem e "mexer aqui tem implicações ali”). É um bom quadro para pensarmos que actividades como as APC só terão sucesso se os próprios professores se empenharem e, mais importante ainda, mudarem eles próprios a concepção do computador e da Internet, em particular. Muitos professores, diante do generalizado fenómeno de trabalhos dos alunos com bom no "copy-paste" da Internet, resolvem desincentivar a pesquisa na Web, desperdiçando a biblioteca mundial digital, em vez de a recomendarem num pressuposto ético e crítico. Há poucas dúvidas, porém, que as "escolas que aprendem" [3] deverão ter uma atitude nova e desafiadora na sociedade e as tecnologias, também usadas "em família", são um excelente instrumento de mudança.

b) Vigostsky [4] está na base daquilo a que poderíamos chamar "construti- 
vismo social". A ideia de construtivismo (além de alguns exageros mais do passado do que do presente) marca a qualidade do ensino. $O$ aluno, bem sabemos, não é um receptáculo vazio a instruir mas alguém com um quadro, não só cognitivo mas psico-bio-socioafectivo, que condiciona a aprendizagem. Vigostsky, cronologicamente antes do surgimento da actual sociedade da informação, introduziu com acutilância a importância do meio e de toda a estrutura social no processamento do conhecimento. A sua noção de ZDP (Zona de Desenvolvimento Próximo) ajudar-nos-á a enquadrar as APC correctamente, pelos três níveis de aproximação: apropriação, participação guiada, e contextualização sócio-institucional (ver Figura 1). Este último nível, pode ser hoje, altamente potenciado pela Internet!

c) Thomas Gordon e a sua escola humanista influencia a abordagem das emoções e da comunicação afectiva, quer na família [5], quer na escola [6]. Os seus ideais e, mais ainda, o seu espírito de recomendações práticas, pode conferir qualidade a muitas práticas pedagógicas. Este autor propõe a operacionalização de comportamentos por parte dos educadores que podem ser da maior utilidade, principalmente hoje, uma vez que o objectivo da escola democrática e do diálogo tendem a ser confundidos com a ausência de regras.

d) As TIPS (Teachers Involving $\mathrm{Pa}$ rents in Schoolwork) foram desenvolvidas pela escola de Johns Hopkins University e têm em Epstein o seu principal precursor [7, 8]. São actividades elaboradas por professores e dirigidas aos alunos e aos seus familiares, para realizar em casa. As APC que propomos têm muitas afinidades com estas iniciativas (ver muitos exemplos em [9]), distinguindo-se, porém, pela centralidade do computador e da Internet, além de outras linhas metodológicas distintas.

e) Podem também ser feitas pontes entre as APC e as "webquests". Dodge propõe actividades de aprendizagem dirigidas aos alunos usando a Internet como fonte de informação [10]. Estas tarefas incluem etapas concretas, como contextos, processos, sugestões, avaliação, etc., que, de alguma forma, temos também nas
APC. A "nuance", porém, está no envolvimento central dos pais nos desafios que propomos.

Muito mais nomes subjacentes a ideias importantes que, de forma mais ou menos directa, sustentam as APC podem ser referidos (Piaget, Papert e De Bono, são só alguns exemplos). Concentremo-nos, porém, nas fontes de inspiração atrás indicadas.

É importante sublinhar, também, que o acompanhamento pedagógico na exploração dos recursos digitais é crucial.

Em casa, como na escola, bons programas de computador ou a excelente fonte de informação que é a Internet podem tornar-se estéreis ou mesmo negativos se não foram acompanhados por pessoas e materiais que ajudem os alunos a reflectir sobre a informação e os processos desenvolvidos. Os alunos tendem a «correr de- pressa» as aplicações e os browsers, não tirando, muitas vezes, o devido proveito educativo dos recursos.

Temos feito alguma reflexão e alguns estudos que reforçam a necessidade de acompanhamento pedagógico de recursos digitais, e que se projectam também na ideia das APC [11].

Na Figura 1 apresentamos um diagrama esquemático, que, de alguma forma, sintetiza e enquadra o ambiente teórico das APC (os exemplos referidos fazem referência à APC de Química, apresentada em artigo à parte neste Boletim).

Terminamos esta secção apresentando aquilo que poderia ser uma definição de APC (Actividades com Pais no Computador): são actividades de aprendizagem, propostas pelos professores, que envolvem os pais (ou outros familiares), os filhos e o computador.

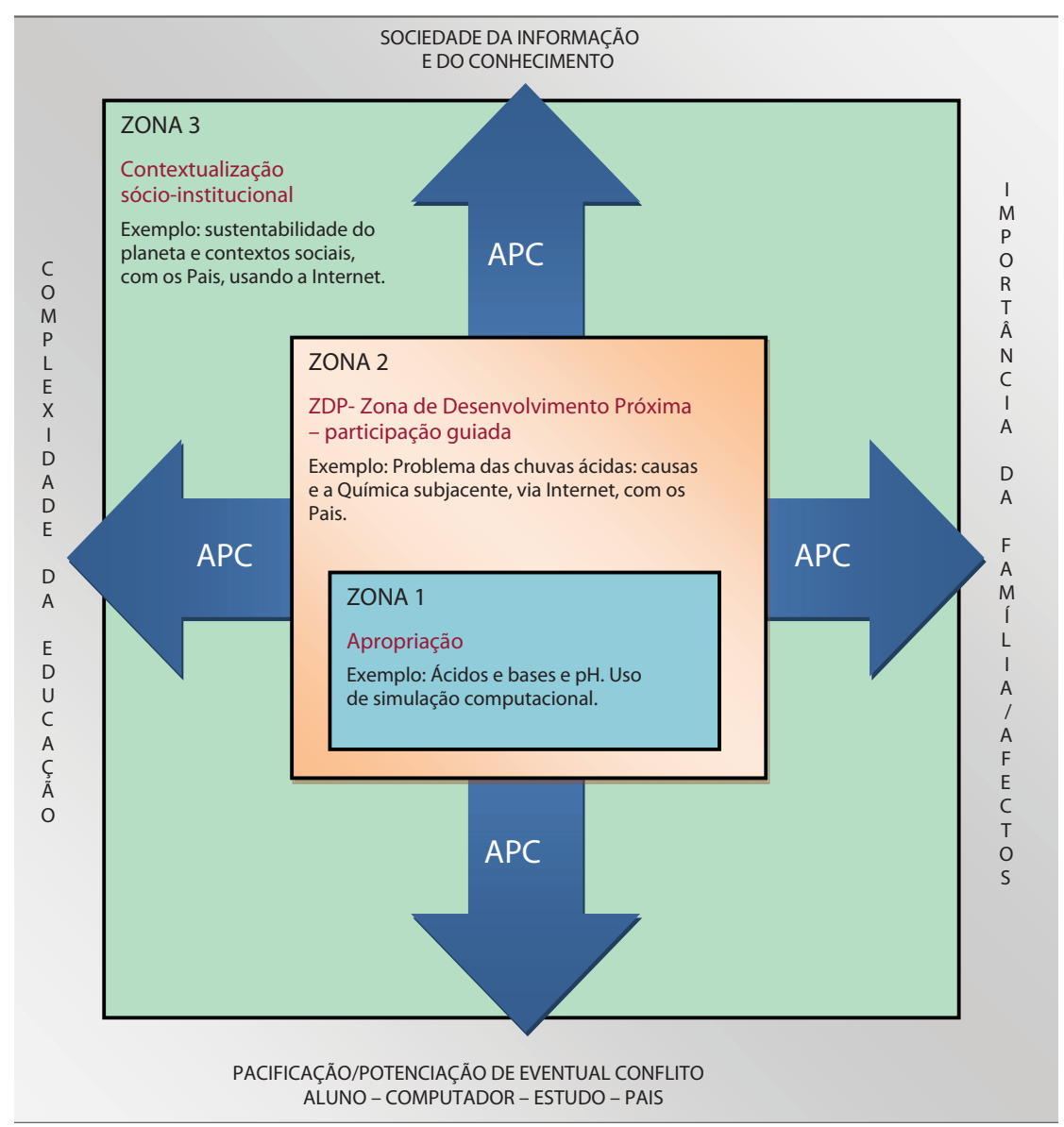

Figura 1 - Diagrama esquemático de enquadramento teórico de uma APC 


\section{Principals Linhas de Força}

$\mathrm{Na}$ senda de ideias já expressas na secção anterior, apresentamos aqui as principais linhas de força de APC, agora de uma forma mais pragmática.

Para nos tornarmos mais claros e sintéticos usaremos itens em vez de prosa e dividiremos estes aspectos em dois grupos que intitularemos a) "Cenários de ideias" e b) "Passos das APC":

\section{a) Cenários de ideias}

1- Mudança de atitude e mentalidade do professor (educação com sensibilidade construtivista, atenta à complexidade e à sociedade de informação).

2- Crescer em espírito crítico, ajudando os filhos, mesmo diante de quadros e ferramentas medíocres, a observar, criticar e escolher valores. Deve, pois, substituir-se a atitude (muito frequente nos educadores) de "não deixar ver" pela atitude de "ver com"... e tirar proveito.

3- Os pais colaboram na aprendizagem dos filhos.

4- ...Mas isso não quer dizer, muito pelo contrário, que "fazem os trabalhos de casa dos filhos", até porque ...

5- Há actividades e tempos de trabaIhos de casa (os mais importantes) que devem ser feitos individualmente pelos alunos.

6- O computador pode ser "amigo da aprendizagem", janela para o mundo (Internet).

7- O computador pode ser rede de comunicação, colaboratividade e afectividade.

8- Alunos e pais devem fazer os seus registos, em papel ou via computador. Estes registos evitam que as coisas se façam depressa e dispersivamente demais, tirando-se mais proveito pedagógico.

9- Uma APC deve equilibrar algumas tarefas/perguntas simples e de resposta simples com outras de carácter mais aberto, complexo e "rasgado".

10-Sempre que possível, propor a versão web da APC, com o envio automático para o professor, dos registos das actividades.

\section{b) Passos das APC}

(Para compreender melhor, ver artigo neste Boletim com exemplo concreto)

A- Pedido de colaboração dos pais (ou outros familiares) e explicação genérica de funcionamento.

B- Contextualização do conteúdo/ contexto de aprendizagem e proposta de actividade.

C- Área de trabalho individual (pode ou não envolver o computador).

D- Área de trabalho colaborativo (pais - alunos).

E- Rubrica "Para continuar", pesquisa que garante a abertura e a continuidade das APC.

F- Avaliação de todos os intervenientes.

Nota: A zona A, com a rotina das APC, poderá depois simplificar-se ou mesmo desaparecer.

Além do exemplo concreto de Carla Morais apresentado neste Boletim, outras ideias podem já ficar no ar, usando, nomeadamente, jogos de natureza comercial, dos quais se pode tirar proveito pedagógico. A palavrachave é, em grande medida, a criatividade! Assim, podem realizar-se APC interessantes, por exemplo, além da Química, à volta dos seguintes ambientes digitais:

- Área de Desporto: Estratégia táctica futebolística

- Área de Matemática: Questões de lógica

- Geografia: Previsão do tempo ou "preparando uma viagem"

- Física: Explorando o céu

- Economia: A problemática da bolsa

- Urbanismo: Planeamento urbano

- Comunicação: Explorando criticamente o msn

- etc.

\section{Projectos de Continuidade}

O exemplo apresentado neste Boletim $S P Q$ é só um entre muitos possíveis. Quer associar-se a esta proposta alguma flexibilidade, importando algumas das generalidades definidas na secção 3 e o cenário fundamental de propor aprendizagem no triplo pilar pais-alunos-computador. Outros exemplos, alguns já experimentados, podem indicar-se com graus de "ou- sadia" variados, usando recursos mais ou menos populares no universo dos alunos, mas extensíveis, com toda a certeza a qualquer contexto disciplinar e a vários patamares etários.

Neste momento, o projecto associado às APC está em crescendo prevendose, a breve trecho, as seguintes evoluções:

A- Optimização de página web associada ao projecto com funcionalidades como:

a1) Conjunto organizado por áreas disciplinares e níveis etários de APC.

a2) Existência de mais áreas de submissão de APC. Estas serão acumuladas e disponibilizadas num "limbo" e, depois, eventualmente, certificadas por um grupo de peritos.

a3) Facultar um "esqueleto geral" para APC on line, para que, de forma fácil, qualquer professor crie a sua APC e a disponibilize on line para os seus alunos e respectivos pais, sem dominar qualquer técnica de programação.

a4) Disponibilizar um conjunto de textos relativos aos contextos teóricos que sustentam as APC.

a5) Organizar uma área de relatos de "Boas práticas de APC", incluindo as respectivas avaliações.

a6) Área de FAQs em APC.

a7) Fórum de discussões sobre APC ... e professores, pais e alunos. Algumas APC, de facto, podem ter continuidades em ambientes colaborativos complementares, usando interfaces de comunicação como fóruns, chats, etc.

B- Monitorização sistemática de experiências no terreno.

C- Burilação dos itens A - F do esquema geral de APC. Particularmente, o item $\mathrm{F}$, de avaliação poderá ser ajustado e/ou ter diferentes perfis.

D- Criar um conjunto de APC particularmente desafiantes, usando estruturas digitais absolutamente não (aparentemente) pedagógicas (passam a 
sê-lo por estímulo orientado do espírito crítico).

E- Formar com intensidade e profundidade particular um conjunto de professores ("agentes TIC nas escolas", Directores de turma, etc.) para servirem de elementos multiplicadores da utilização de APC.

F- Fazer algum estudo no sentido de experimentar "forçar" a inserção de APC nos curricula e nas práticas pedagógicas regulares.

G- Estimular o contacto com parceiros de instituições educativas de todo o mundo para estudar, conceber, implementar e avaliar APC.

\section{Notas Finals}

Esperamos ter conseguido partilhar o nosso entusiasmo em relação a estas actividades que, assim "instituídas" e popularizadas, podem ajudar a promover uma educação mais global, mais integrada e, sobretudo, mais adaptada à sociedade de informação e do conhecimento e, desta forma, mais adaptada às necessidades dos nossos tempos.

Não se trata de ter uma posição fundamentalista, como se estas actividades fossem "a resposta" aos problemas de educação. São, isso sim, "um dos caminhos”. Convém, aliás, não esconder os constrangimentos associados a estas iniciativas. Além do principal, já mencionado, que se prende com as inércias intrínsecas dos sistemas (professores, pais, escolas, sistema educativo em geral), há dificuldades de natureza social que convém ter em conta. Há alunos cujos pais têm patamares culturais muito baixos e onde as $\mathrm{APC}$, principalmente nos níveis mais avançados, se tornarão complicadas (poderão ser, nestes casos, porém, estímulos de uma formação complementar na família, através da escola, pelos alunos). O próprio sistema de exames e a existência de numerus clausus para as entradas nas universidades, em moldes muito clássicos, pode, indirectamente, "desestimular" estas actividades. Pior ainda, o excessivo 'endeusamento' social e familiar dos rankings escolares pode substituir as pedagógicas APC pelas

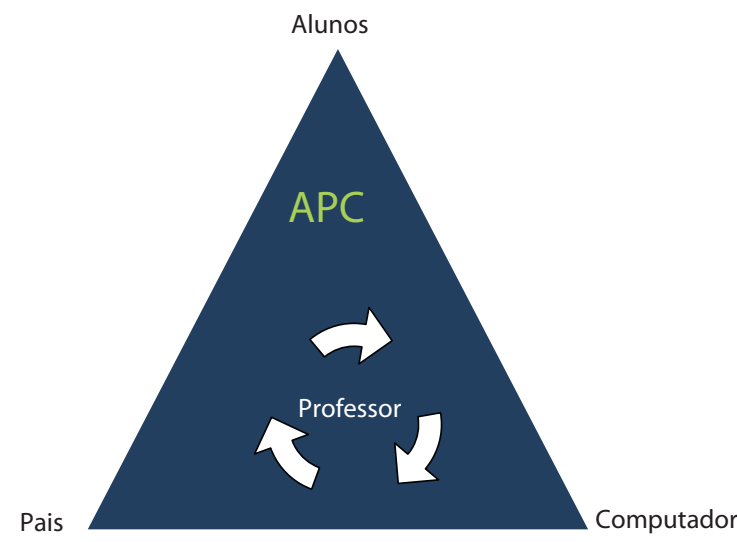

Figura 2 - O professor é o elemento dinamizador de uma APC

aberrações estratégicas dos "pais a fazerem os trabalhos de caso pelos filhos"...

Assistimos a um quadro que, embora compreensível, apresenta, quanto a nós, perigos sociais e falta de noção de "médio-longo prazo educativo": os pais proíbem os filhos de aceder ao computador e à Internet, como castigo de não estudarem. Ora, tal atitude parecerá tão despropositada amanhã (ou hoje?) como a de proibir os filhos de ler livros, como castigo de más notas... O caminho é outro... não tanto a "luta" com o computador mas a conciliação feliz, acompanhada e integrada, do triângulo pais-alunos-computador! (Figura 2).

O professor, como sempre em educação, assume um papel estimulador fundamental!

\section{Agradecimentos}

Agradeço à minha colega Filomena Gaspar com quem trilhei os primeiros caminhos da problemática do envolvimento dos pais na aprendizagem dos filhos, com quem esbocei a problemática dos roteiros de exploração de software educativo. Agradeço ainda a Jacinta Paiva pelos complementos e sugestões. Estou grato à Carla Morais pelo esboço do exemplo de uma APC no domínio da Química.

\section{REFERÊNCIAS}

[1] Alch, M. L. (2000). Get ready for the net generation. Training \& Development. Disponível em http://www.allbusiness.com/population-demographics/ demographic-groups-generationx/11437547-1.html consultado em 15 de Julho de 2010.

[2] Senge, P. et al (1994). The Fifth Discipline Fieldbook (Strategies and Tools for Building a Learning Organization), New York, Doubleday Currency.

[3] Senge, P. et al (2000). Schools That Learn, Nicolas Brealey Pub. London.

[4] Vygotsky, L.S. (1978). Mind in society: The development of higher psychological processes. Cambridge, MA: Harvard University Press.

[5] Gordon, T. (2000). Parent Effectiveness Training, P.E.T.. New York, NY: Random House.

[6] Gordon, T. \& Burch, N. (2003). Teacher Effectiveness Training, T.E.T.. New York, NY: Three Rivers Press.

[7] Epstein, J. L. et al. (2002). School, Family, and Community Partnerships: Your Handbook for Action, Second Edition. Thousand Oaks: Corwin Press.

[8] Epstein, J. L., Van Voorhis, F. L., Batza, C. (2001). Teachers Involve Parents in Schoolwork (TIPS) Science Prototype Activities for Grade 3. Baltimore, MD: Center on School, Family, and Community Partnerships, Johns Hopkins University.

[9] TIPS (2005). Teachers Involve Parents in Schoo/work. Disponível em http:// spearfish.k12.sd.us/west/Specials/ Penny/Teacher\%20Involve/ScienceAct.htm, consultado em 15 de Julho de 2010.

[10] WebQuest.Org. Disponível em http:// webquest.sdsu.edu/webquest.html, consultado em 15 de Julho de 2010.

[11] Paiva, J. C. \& Costa, L. (2010). Exploration Guides: improving the use of educational software. Journal of Chemical Education. 87 (6), 589-591. 


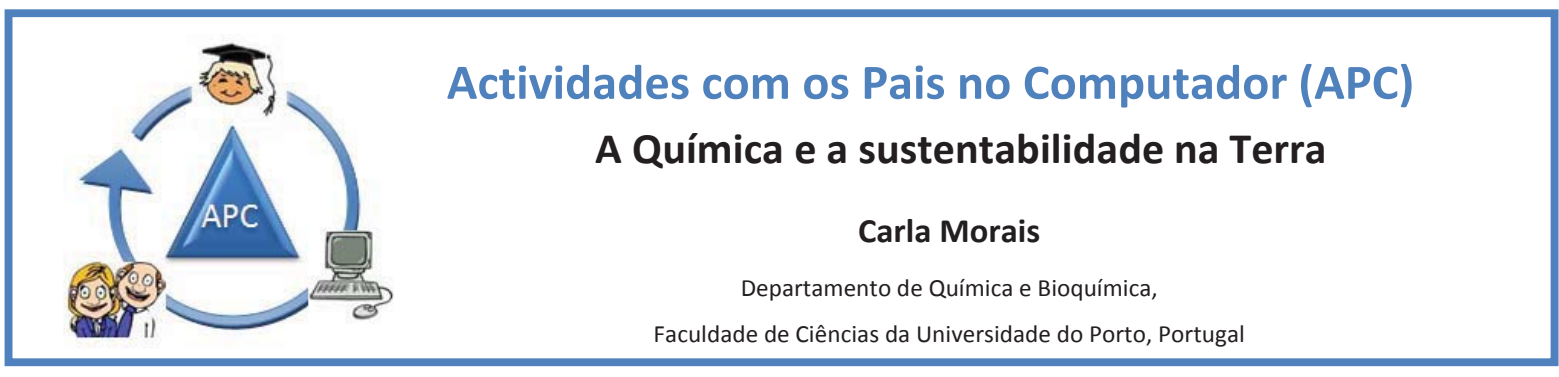

\title{
A - Caros alunos e pais/familiares
}

Neste trabalho propomos que realizem algumas pesquisas relacionadas com conteúdos curriculares de Química e que debatam em conjunto a necessidade de pensar e pôr em prática soluções de sustentabilidade que, no mínimo, assegurem a manutenção das condições actuais de vida na Terra.

É muito importante fazer todos os registos numa folha de papel e anexá-la a este documento. A secção C é para ser realizada pelo aluno, individualmente, e as secções $D, E$ e $F$ dizem respeito às tarefas propostas para o aluno e os pais (ou familiares) realizarem em conjunto.

NOTA: Façam os vossos registos numa folha de papel ou, digitalmente, num ficheiro de texto no computador.

\section{B - Contexto}

A Ciência, em geral, e a Química, em particular, têm um papel importantíssimo em assegurar a sustentabilidade da vida na Terra. Assim, ao longo do 8. ano temos vindo a aprofundar os nossos conhecimentos científicos de modo a podermos contribuir para esta sustentabilidade. Por exemplo, quando não estamos a esgotar os recursos nem a degradar o meio ambiente, estamos a contribuir para que a vida no futuro não fique em risco. As tarefas que propomos nesta APC vão contribuir para que, conjuntamente com os teus pais/família, reflictas e compreendas ainda melhor a necessidade e o dever de

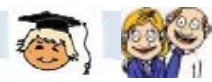
todos nós assegurarmos a qualidade de vida no nosso planeta.

Obrigado pela colaboração!

\section{C - Área de trabalho individual}

Recordando algumas das abordagens feitas nas aulas, começa por ler o seguinte texto:

\begin{abstract}
«É possível fixar e transformar o dióxido de enxofre presente nos fumos das chaminés industriais em gesso. Do mesmo modo, cada vez mais veículos automóveis são equipados com catalisadores (ou conversores catalíticos) que reduzem a quantidade de óxidos de azoto expelidos para a atmosfera, responsáveis, juntamente com os óxidos de enxofre, pelas chuvas ácidas. Os benefícios ambientais e para a vida de todos, a longo prazo, compensam largamente os investimentos adicionais a curto prazo a que estas medidas obrigam. Entretanto, o crescente uso de gás natural como combustível em fábricas e centrais termoeléctricas contribuirá para a diminuição da poluição atmosférica, pois os produtos da combustão são praticamente só dióxido de carbono e água. Note-se, contudo, que estas substâncias, embora não poluentes, são gases responsáveis pelo efeito de estufa». (Fiolhais et al., 2007) (a)
\end{abstract}

C1. Qual é a fórmula química do dióxido de enxofre?

C2. Procura em sítios na Internet que outros óxidos de enxofre e óxidos de azoto existem. Escreve as suas respectivas fórmulas químicas.

C3. Pesquisa na Internet a relação destes óxidos com as chuvas ácidas e investiga também que outras substâncias químicas integram a composição destas chuvas.

C4. Além do gás natural, que outros combustíveis são usados nas centrais termoeléctricas? 
C - Área de trabalho individual (continuação)

C5. Pesquisa na Internet os principais gases com efeito de estufa (GEE), ordenando-os do menos abundante para o mais abundante.

C6. Utiliza a simulação computacional sobre o efeito de estufa disponível em http://phet.colorado.edu/en/simulation/greenhouse, que permite seleccionar a concentração de gases com efeito de estufa durante a idade de gelo, no ano 1750, hoje, ou no futuro e observar a evolução da temperatura.

- Compara a concentração de GEE no ano 1750 e na actualidade.

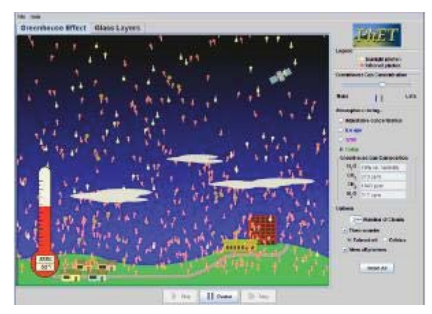

- Procura explicar porque é que a temperatura aumenta à medida que aumenta a concentração de GEE.

\section{D - Área de trabalho colaborativo pais/alunos}

D1. Usando sítios da Internet ou outros recursos, recomenda-se que o aluno faça uma breve síntese, ao seu $\mathrm{pai} / \mathrm{mãe}$ ou outro familiar, dando conta que o recente desenvolvimento científico e tecnológico trouxe importantes benefícios para a sociedade, mas também trouxe consequências preocupantes para a sustentabilidade da vida na Terra: aquecimento global, efeito de estufa, chuvas ácidas, poluição atmosférica, esgotamento dos combustíveis fósseis, entre outras.

D2. “Economizar os combustíveis fósseis, responsáveis pelo aumento da acidez das chuvas, constitui não só uma poupança de recursos não renováveis mas também uma contribuição para a qualidade do ambiente". Investiguem, partindo de um motor de busca genérico ou de um portal de ciência:

- Soluções alternativas para minimizar a dependência do nosso país dos combustíveis fósseis.

- Alguns dos efeitos devastadores das chuvas ácidas.

D3. Partilha com os teus pais o que já aprendeste sobre soluções ácidas, básicas e neutras explorando a simulação computacional "Determinação do pH" (Folhais et al., 2007) ${ }^{(b)}$ disponível em http://www.emultimedia.com.pt/simulacaoph/

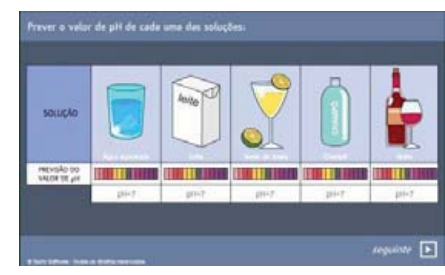

D4. O efeito de estufa é benéfico para a manutenção da vida na Terra, pois permite que a Terra mantenha uma temperatura média de cerca de $15{ }^{\circ} \mathrm{C}$. Contudo, este efeito está a aumentar por causa da actividade humana, o que tem consequências para a sustentabilidade da vida na Terra. Pesquisem, na Internet, e reflictam sobre o que poderá fazer Portugal para reduzir as emissões de GEE. (DICA: palavras-chave em motores de busca de sites: Protocolo de Quioto/Cimeira de Copenhaga).

\section{E - Para Continuar}

E1. Apesar desta investigação, podem ficar algumas dúvidas ainda no ar. Registem todas as dúvidas para depois o aluno tentar esclarecer na escola com o professor.

E2. Discutam a importância que a Internet, em particular, teve, tem e pode vir a ter para ajudar a resolver os flagelos que afectam actualmente a qualidade de vida na Terra.

E3. Na sequência desta reflexão, indiquem que práticas diárias passarão a integrar a vida de cada membro da família, de modo a contribuir para assegurar a sustentabilidade da vida na Terra.

E4. Conscientes de que muito mais poderá ser feito, recorram à Internet e em conjunto:

- Planeiem uma campanha de sensibilização que incentive a população a não desperdiçar água.

- Elaborem panfletos de divulgação sobre a separação do lixo doméstico, local de depósito e modo de tratamento do mesmo, como forma de intervenção junto da comunidade. 


\section{F - Avaliação de todos os intervenientes}

Muito obrigado! Antes de mais, queremos agradecer pela colaboração e por todo o empenho colocado na realização desta actividade. Pedimos, por favor, que façam o preenchimento da tabela seguinte e que registem quaisquer outras observações que entendam pertinentes.

\section{Preenchimento da tabela:}

Assinalem com uma $\mathrm{X}$ a coluna que melhor corresponde à vossa opinião sobre o item em observação. Utilizem, para apreciar cada item, a escala que a seguir se apresenta:

1- Muito Mau; 2- Mau; 3- Razoável; 4- Bom; 5- Muito Bom.

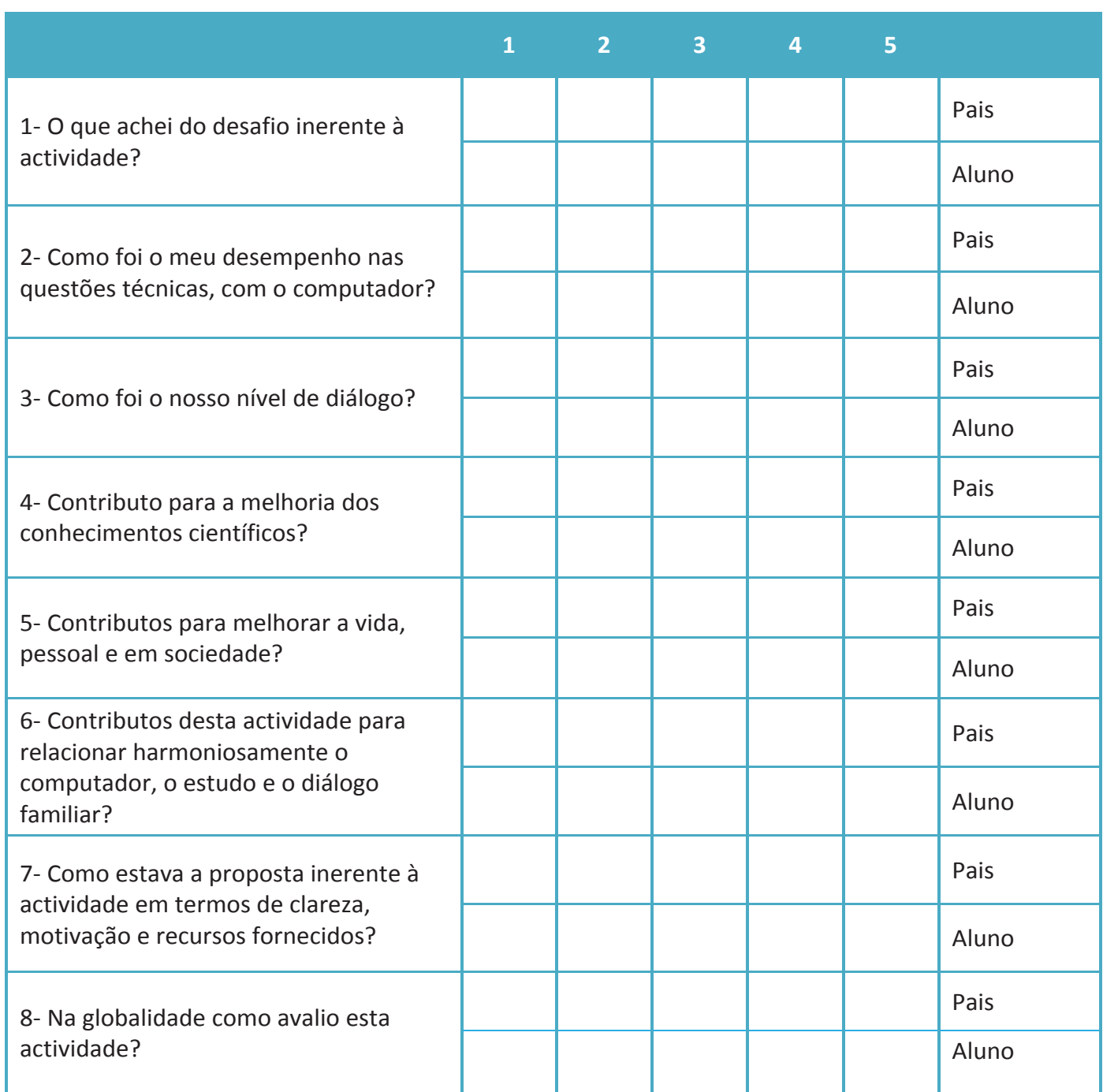

Outras observações:

Grato,

O Professor

(a) C. Fiolhais; M. Fiolhais; V. Gil; J. Paiva; C. Morais; S. Costa. 8CFQ - Ciências Físico-Químicas 8.o ano. Texto Editores, Lisboa (2007). (b) C. Fiolhais; M. Fiolhais; V. Gil; J. Paiva; C. Morais; S. Costa. Manual Multimédia 8CFQ. Texto Editores, Lisboa (2007). 


\section{António V. Xavier Seminars}

Thursdays 11:00 AM - ITQB Auditorium - Oeiras

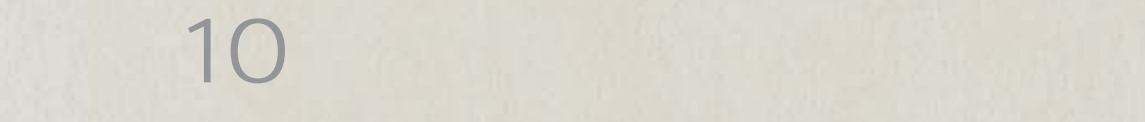

www.itgb.unl.pt

September 16 Maria J oão Saraiva ICBAS/IBMC-UP

Role of the heat shock response in misfolding disorders of extracellular deposition

October 7 Leonor Cancela FCT-UA

New players in skeletogenesis and tissue calcification: a fish story

November 4 Miguel Castanho FM-UL

Molecular biophysics goes live in biomedicine: turning peptides into drugs

December 2 Miguel Che Soares IGC

How we deal with foreigners: the benefits of tolerance

January 13 Pedro Moradas Ferreira ICBAS/ IBMC-UP

The signal: death or longevity? Bioactive lipids modulating ageing

February 10 Fernando Pina FCT-UNL

Chromogenic compounds for smart materials

March 3 Wanda Viegas IST-UTL

Differential remodelling of chromatin topology in small and large genomes

April 7 Eduardo Ducla Soares FCUL

Brain biophysics

May 5 Mário Barbosa FE e INEB-UP

Cell-biomaterial interactions at the nanoscale

June 9 António Granado FCSH-UNL

Science journalism is dead. Now what?

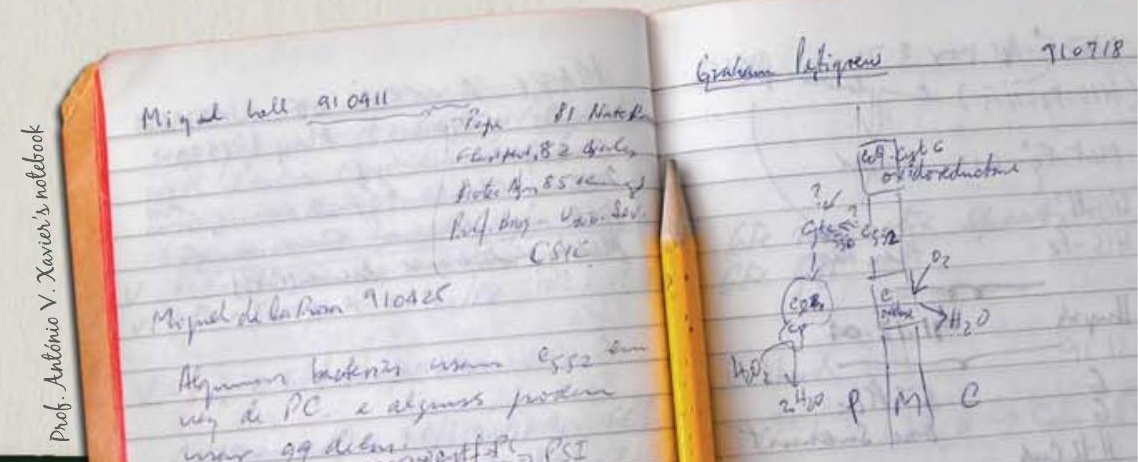

